\title{
Article \\ Core Needle Biopsy Enhances the Activity of the CCL2/CCR2 Pathway in the Microenvironment of Invasive Breast Cancer
}

\author{
Marja Heiskala *, Kristiina Joensuu and Päivi Heikkilä
}

check for updates

Citation: Heiskala, M.; Joensuu, K.; Heikkilä, P. Core Needle Biopsy Enhances the Activity of the CCL2/CCR2 Pathway in the Microenvironment of Invasive Breast Cancer. Onco 2022, 2, 1-18. https:// doi.org/10.3390/onco2010001

Academic Editor: Fred Saad

Received: 4 December 2021

Accepted: 27 December 2021

Published: 30 December 2021

Publisher's Note: MDPI stays neutral with regard to jurisdictional claims in published maps and institutional affiliations.

Copyright: (C) 2021 by the authors. Licensee MDPI, Basel, Switzerland. This article is an open access article distributed under the terms and conditions of the Creative Commons Attribution (CC BY) license (https:// creativecommons.org/licenses/by/ $4.0 /)$.
Department of Pathology, University of Helsinki, 00100 Helsinki, Finland; kristiinajoensuu7@gmail.com (K.J.); paivi.heikkila@helsinki.fi (P.H.)

* Correspondence: maria.heiskala@gmail.com

Simple Summary: Core needle biopsy $(\mathrm{CNB})$ is used to diagnose clinically and/or radiologically suspicious solid foci in breast tissue. The impact of CNB on the host's immunologic response towards the tumor has not previously been investigated in humans. We compared the activation level of the CCL2/CCR2 pathway, a critical player in the recruitment of myeloid derived suppressor cells into tumor sites, in samples from CNBs to those from the corresponding resected tumors. We found a significant upregulation of the activity post-biopsy, marked by an increased infiltration of immunosuppressive monocytes/macrophages. The underlying change in the context-dependent function of CCL2 may lead to a weakening of tumor surveillance not only in the local tumor microenvironment but also in the peripheral immune machinery. The findings promote the importance of early innate immunity, supporting interventions to further improve the prognosis of breast cancer.

Abstract: The use of core needle biopsy (CNB) as a means to verify malignancy preoperatively is a paradigm in current breast cancer care, and the risk of enhancing tumor development by this procedure has been considered insignificant. Experimental work in mice has shown preoperative biopsies to increase tumor supportive elements in the microenvironment, whereas, in humans, the impact of CNB on the host's immunologic response has not been investigated. In this pilot study, we compared the expression of CCL2/CCR2 pathway components at the protein level in samples from $\mathrm{CNBs}$ to those from the corresponding resected tumors from 52 patients with primary breast cancer. We found an increased expression of CD163, CD14 and CCR2 in monocytes/macrophages and a slight decrease of CCL2 in the malignant epithelium in the tumors after the biopsy. The increased infiltration of immunosuppressive monocytes/macrophages and the decreased tumor cell CCL2 expression, presumably due to the CCR2 availability-dependent CCL2 internalization, suggest that CNB enhances the activity of the CCL2/CCR2 pathway, and this finding warrants confirmatory examination. The switch in the context-dependent role of CCL2 on the polarization of macrophages may lead to increased tumor supportive function both locally and in the peripheral immune machinery. The future directions in breast cancer should include early interventions to support the tumor surveillance of the host.

Keywords: breast cancer; CCL2/CCR2 pathway; immunologic response to malignancy

\section{Introduction}

Patients with clinically and/or radiologically malignant lesions in breast tissue undergo core needle biopsy (CNB) to verify the diagnosis of invasive cancer. CNB has a high overall accuracy [1], and it is currently established as a critical part in the process of diagnosing breast tissue lesions. Malignant tumors are removed as soon as the pathologic report of the needle sample confirms the diagnosis, and investigations on the spread of the disease have been performed, typically with a delay of two to four weeks. The impact of CNB on the biology of the tumor is largely unknown. In an early study in breast cancer comparing excision surgery only to excision preceded by needle biopsy, no difference in 
prognosis between the groups was detected [2]. Both fine needle biopsy (FNAB) and CBN have been shown to induce tumor cell seeding in needle tracts and/or blood and lymph vessels [3-7]. An increase in the sentinel node and late occurring distant metastases in patients that had undergone CNB as compared to those diagnosed by FNB was described by Hansen et al. [7] and Sennerstam et al. [8], while Liikanen et al. [3] showed no difference. Dislodging neoplastic cells from tumors during biopsy is supported by their lack of cohesiveness, and loose tumor cells may also end up in the circulation or lymphatic system. Although the viability of the displaced tumor cells has been reported as low, a risk of implantation metastases has not been entirely excluded [9-12]. The possible change in the microenvironment of a tumor after biopsy has not been explored in humans. In a controlled study of mice, a needle biopsy significantly increased the frequency of distant metastases, and the inflammation induced by the procedure was determined to be the causative factor [13]. We have previously shown that tumor-supporting elements in the microenvironment of breast cancer increase during tumor progression [14]. The activation of the complementary pair of CCR2/CCL2 and/or CCR5/CCL5 and the resulting CD14+ monocyte count increase form the hallmark of human inflammatory disease in general [15]. They are also an established feature in malignancies, especially in breast cancer [16]. In this study, we compared samples from 52 pairs of CNB and the corresponding tumors excised after biopsy to detect and analyze the possible differences in the tumor microenvironment that emerged during the 8-82-day time period that elapsed between biopsy and surgery. The expression of CCL2 at the protein level in tumor cells and the microenvironment and the frequency of CCR2, DC163 and CD14 protein-expressing monocytes/macrophages were evaluated.

\section{Materials and Methods}

\subsection{Patients and Tissue Samples}

Paraffin-embedded tissue blocks from the diagnostic core needle biopsies (CNB) from primary breast cancers of 52 patients and their corresponding surgically resected tumors (tumor) were collected from the archives of the Department of Pathology of the University Hospital of Helsinki. The tumors were resected during the year 2016. The time lapse between the CNB and the surgical excision varied between 8 and 82 days (mean 28 days, median 25 days). The sizes of the tumors varied from $4.5 \mathrm{~mm}$ to $50.0 \mathrm{~mm}$ (mean $20.8 \mathrm{~mm}$, median $20.0 \mathrm{~mm}$ ).

The clinicopathological characteristics and the information regarding tumor-related prognostic parameters were derived from the reports of the Department of Pathology of the University Hospital of Helsinki. The ER, PR, HER2 and Ki67 expression data and the histological specificity and the grade of the tumor were recorded based on the analysis of the biopsy. In two cases, the nodal status was not reported. The data are summarized in Table 1. This study was conducted according to the guidelines of the Declaration of Helsinki and approved by the Ethics Committee of the Hospital District of Helsinki and Uusimaa (HUS/861/2020).

Table 1. Clinicopathological characteristics.

\begin{tabular}{ccc}
\hline age at surgery & $<50$ year & $\geq 50$ year \\
\hline nodal metastases $^{1}$ & $9(17.3 \%)$ & $43(82.7 \%)$ \\
\hline tumor size & - & $27(51.9 \%)$ \\
\hline grade & $23(44.2 \%)$ & $\geq 20 \mathrm{~mm}$ \\
\hline & $<20 \mathrm{~mm}$ & $26(50 \%)$ \\
\hline
\end{tabular}


Table 1. Cont.

\begin{tabular}{|c|c|c|}
\hline ER status & - & + \\
\hline & $4(7.7 \%)$ & $48(92.3 \%)$ \\
\hline \multirow{2}{*}{ PR status } & - & + \\
\hline & $10(19.2 \%)$ & $42(80.8 \%)$ \\
\hline \multirow[t]{2}{*}{ Ki67 expression } & $<30 \%$ & $\geq 30 \%$ \\
\hline & $31(59.6 \%)$ & $21(40.4 \%)$ \\
\hline \multirow[t]{2}{*}{ HER2 status } & - & + \\
\hline & $47(90.4 \%)$ & $5(9.6 \%)$ \\
\hline \multirow[t]{2}{*}{ Histology 2} & ductal & lobular \\
\hline & $25(48.1 \%)$ & $24(46.2 \%)$ \\
\hline \multirow[t]{2}{*}{ age at surgery } & $<50$ year & $\geq 50$ year \\
\hline & $9(17.3 \%)$ & $43(82.7 \%)$ \\
\hline \multirow[t]{2}{*}{ nodal metastases ${ }^{1}$} & - & + \\
\hline & $23(44.2 \%)$ & $27(51.9 \%)$ \\
\hline \multirow[t]{2}{*}{ tumor size } & $<20 \mathrm{~mm}$ & $\geq 20 \mathrm{~mm}$ \\
\hline & $26(50 \%)$ & $26(50 \%)$ \\
\hline \multirow[t]{2}{*}{ grade } & 1 & $2-3$ \\
\hline & $11(21.2 \%)$ & $41(78.8 \%)$ \\
\hline \multirow[t]{2}{*}{ ER status } & - & + \\
\hline & $4(7.7 \%)$ & $48(92.3 \%)$ \\
\hline \multirow[t]{2}{*}{ PR status } & - & + \\
\hline & $10(19.2 \%)$ & $42(80.8 \%)$ \\
\hline \multirow[t]{2}{*}{ Ki67 expression } & $<30 \%$ & $\geq 30 \%$ \\
\hline & $31(59.6 \%)$ & $21(40.4 \%)$ \\
\hline \multirow[t]{2}{*}{ HER2 status } & - & + \\
\hline & 47 (90.4\% & $5(9.6 \%)$ \\
\hline \multirow[t]{2}{*}{ Histology 2} & ductal & lobular \\
\hline & $25(48.1 \%)$ & $24(46.2 \%)$ \\
\hline
\end{tabular}

${ }^{1}$ Nodal status was not reported in two cases. ${ }^{2}$ The histology of three tumors was non-ductal/lobular: tubular (1) mucinous (1) and micropapillary (1).

\subsection{Immunohistochemistry}

Four-micron-thick sections of the paraffin-embedded (PE) tissue blocks were deparaffinized in xylene and rehydrated. To block endogenous peroxidase, the slides were treated in a PT module (LabVision UK Ltd., Suffolk, UK) in Tris-HCL buffer (pH 8.5) for $20 \mathrm{~min}$ at $98{ }^{\circ} \mathrm{C}$ and with $0.3 \%$ Dako REAL Peroxidase Blocking Solution (Agilent Technologies, Santa Clara, CA, USA) for $15 \mathrm{~min}$. Immunostaining was performed in Auto Stainer 480 (Lab Vision Thermo Scientific Ltd., Cheshire, UK) by exposing to primary antibodies: monoclonal mouse antibodies anti-MCP-1/CCL2 clone $2 \mathrm{~dB}$, dilution 1:5000 (LifeSpan BioSciences, Inc., Seattle, WA, USA), anti-CD14 clone 7, dilution 1:50 (Lab Vision Corporation, Fremont, CA, USA), anti-CD163 clone 10D6, dilution 1:200 (Leica Biosystems Newcastle Ltd., Newcastle upon Tyne, UK) and anti-CCR2 clone 7A7, dilution 1:500 (LifeSpan BioSciences, Inc., Seattle, WA, USA), followed by a 30-min incubation with Dako REAL ${ }^{\mathrm{TM}}$ EnVision $^{\mathrm{TM}}$ Detection System, Peroxidase/DAB+ using mouse/rabbit code K5007 EnVision reagent (Agilent Technologies, Santa Clara, CA, USA). Washing with PBS 0.04\%-Tween 20 took 
place between each step. Sections were counterstained with Mayer's hematoxylin and mounted in mounting medium.

Double staining CD163/CCR2 was started with a 60-min incubation with anti-CD163 mouse monoclonal clone 10D6, $\mathrm{pH}$ 9, at the dilution of 1:200, followed by incubation with Dako EnVision FLEX/HRP detection reagent (SM802) (K8000) for 30 min. Visualization was done by EnVision FLEX Substrate Buffer (SM803) incubation for $10 \mathrm{~min}$. The slides were then treated with sulphuric acid 0.3 M (GC203, Agilent) for $3 \mathrm{~min}$, followed by incubation with anti-CCR2 monoclonal mouse clone 7A7, $\mathrm{pH}$ 9, at the dilution of 1:500 for $30 \mathrm{~min}$. Antigen detection was performed by incubation with Dako EnVision FLEX/HRP detection reagent (SM802) (K8000) for $30 \mathrm{~min}$ and visualization by AEC10HPP Magenda.

For ER, PR and Ki67/MIB1, the percentage of marker-positive tumor cells (range $0-100 \%$ ) was derived from the archive of the University Hospital of Helsinki. Only tumors with HER2 gene amplification were recorded as HER2-positive.

\subsection{Evaluation of the Staining Results}

The expression of CCL2 in the samples was recorded as the fraction of strongly positive epithelial (tumor) cells, based on 3-5 views/sample: $0=$ negative, $1=5 \%-33 \%$ positive cells, $2=34 \%-66 \%$ positive cells and $3=67 \%-100 \%$ positive cells. The criteria for a strong staining were a bright label both in the Golgi apparatus and cytoplasm and a heavy accumulation on the cell membrane. In the surrounding stroma, a fraction of lymphocytes expressed CCL2, and the percentage/score of CCL2-positive cells was recorded accordingly.

The expression of CCR2 was recorded as the number of positive macrophages per $40 \times$ view, based on the mean of 3-5 views. The CCR2-positive monocytes/macrophages were located in the tumor surrounding stroma and, less often, in close contact with the tumor cells. Both locations were evaluated separately.

The amount of CD163 and CD14-positive monocytes/macrophages was recorded as the number of cells per $40 \times$ view, based on the mean of 3-5 views. The stroma surrounding the tumor and the intratumoral stroma, where the macrophages were in close contact with the tumor cells, were evaluated separately.

\subsection{Statistical Methods}

All statistical analyses were performed using SPSS 24.0 for Windows (SPSS Incorporation, Chicago, IL, USA). The differences between the expression of the markers in the $\mathrm{CNBs}$ and the corresponding resected tumors were tested using the paired samples $t$-test. For analyzing the association of the expression of the markers with the clinicopathologic parameters ER, PR, Ki67 and HER2, we used the categorical two-tailed Pearson's chi-square test. For the Pearson's chi-square tests, the cutoff point for negativity vs. positivity was $<+2$ vs. $\geq+2$ for CCL2 and $<$ median vs. $\geq$ median for CD163, CD14 and CCR2. For ER and PR, the cutoff point for positivity was $1 \%$, and for Ki67, $\geq 30 \%$. For HER2, only tumors with positive gene amplification were considered positive. Probability values $p<0.05$ were considered significant.

To detect the possible impact of the tumor size, time lapse between biopsy and tumor resection, histology of the tumor and the other clinicopathological prognostic markers on the difference in the expression of CCL2, CCR2, CD163 and CD14 in CNBs vs. resected tumors, paired $t$-tests were also run separately on small ( $<$ median) and large ( $\geq$ median) tumors; on quickly ( $<$ median) and with delay ( $\geq$ median) resected tumors; on ductal and lobular tumors and on PR+ and PR-, Ki67+ and Ki67-, node+ and node- and grade 1 and grade 2 to 3 tumors. ER+ and ER - and HER2+ and HER2 - tumors were not compared separately due to the low number of ER- (4) and HER2+ (5) tumors in the material. CNBs vs. resected tumor differences were also evaluated separately in patients $<50$ years of age and those $\geq 50$ years. 


\section{Results}

\subsection{Distribution of the CCL2/CCR2 Pathway Components}

CCL2, CCR2, CD163 and CD4 were all widely expressed at the protein level in the samples from both the CNBs and resected tumors. CCL2 expression was detected in the entirety of the malignant epithelial cells and, additionally, in a fraction of lymphocytes in the stroma. CCR2, CD163 and CD14 were expressed in monocytes/macrophages in the peripheral stroma of the tumor and, to a lesser extent, in the intratumoral stroma and in close contact with the cancer cells. We also found the expression of CD163 in the epithelial tumor cells in one pair of a CNB and the corresponding excised tumor. The tumor cells did not express CCR2 nor CD14.

\subsection{Localization of the CCL2/CCR2 Pathway Marker-Positive Monocytes/Macrophages in Tumors}

The CD163 and CD14-positive cells were more frequent in the peripheral stroma of the tumor than in the intratumoral stromal streaks both in the CNBs and resected tumors. CCR2-positive cells were extremely infrequent intratumorally in the biopsies, and their number was low intratumorally in the resected tumors as well. In the peripheral stroma in both the biopsies and resected tumors, they were significantly more abundant (Figure 1).

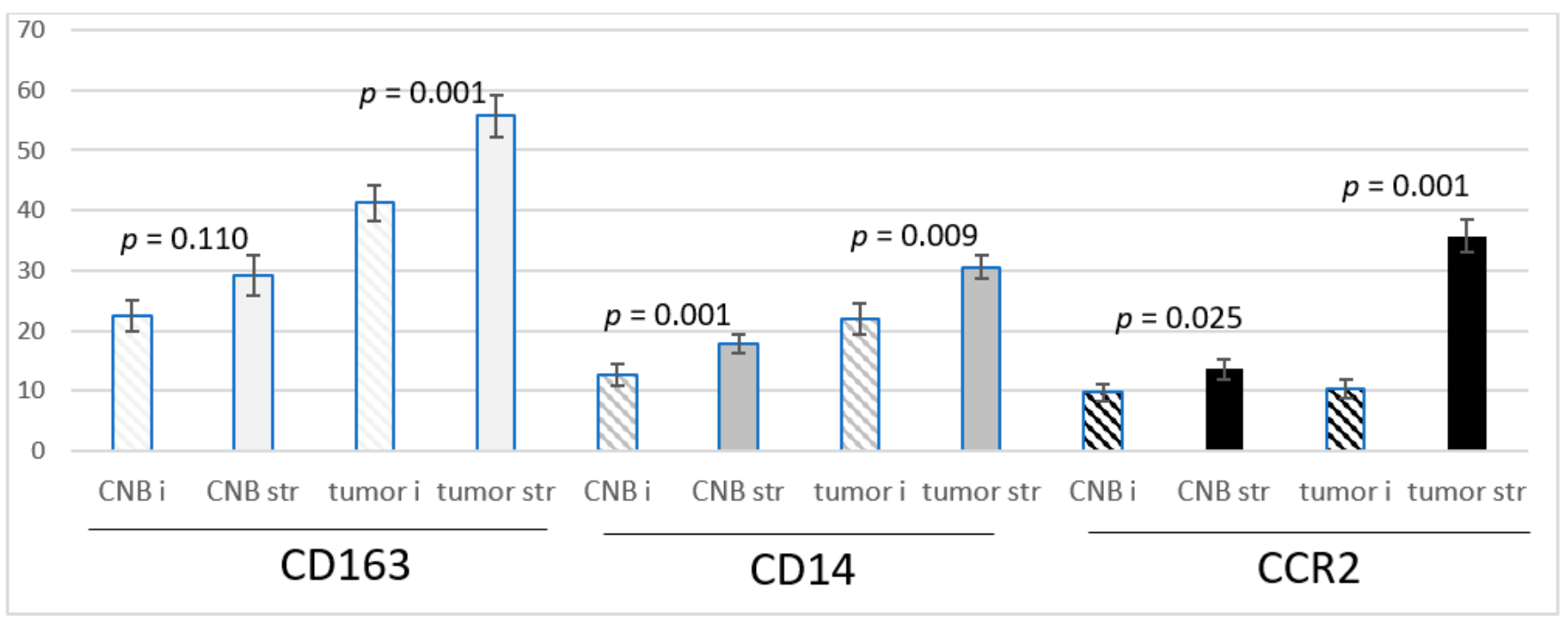

Figure 1. The means +/- SEM of the number of CD163, CD14 and CCR2-positive monocytes/macrophages per $\times 40$ view intratumorally (i) and in the stroma (str) in samples from CNBs (CNB) and the corresponding resected tumors (tumor), and the difference between intratumoral and stromal abundance is shown. Paired $t$-test was used.

Double staining showed that CCR2 and CD163-positive monocytes/macrophages were partially overlapping but separate cell populations, CCR2-positive cells primarily occupying the peripheral stroma and CD163-positive also invading among the tumor cells (Figure 2). 


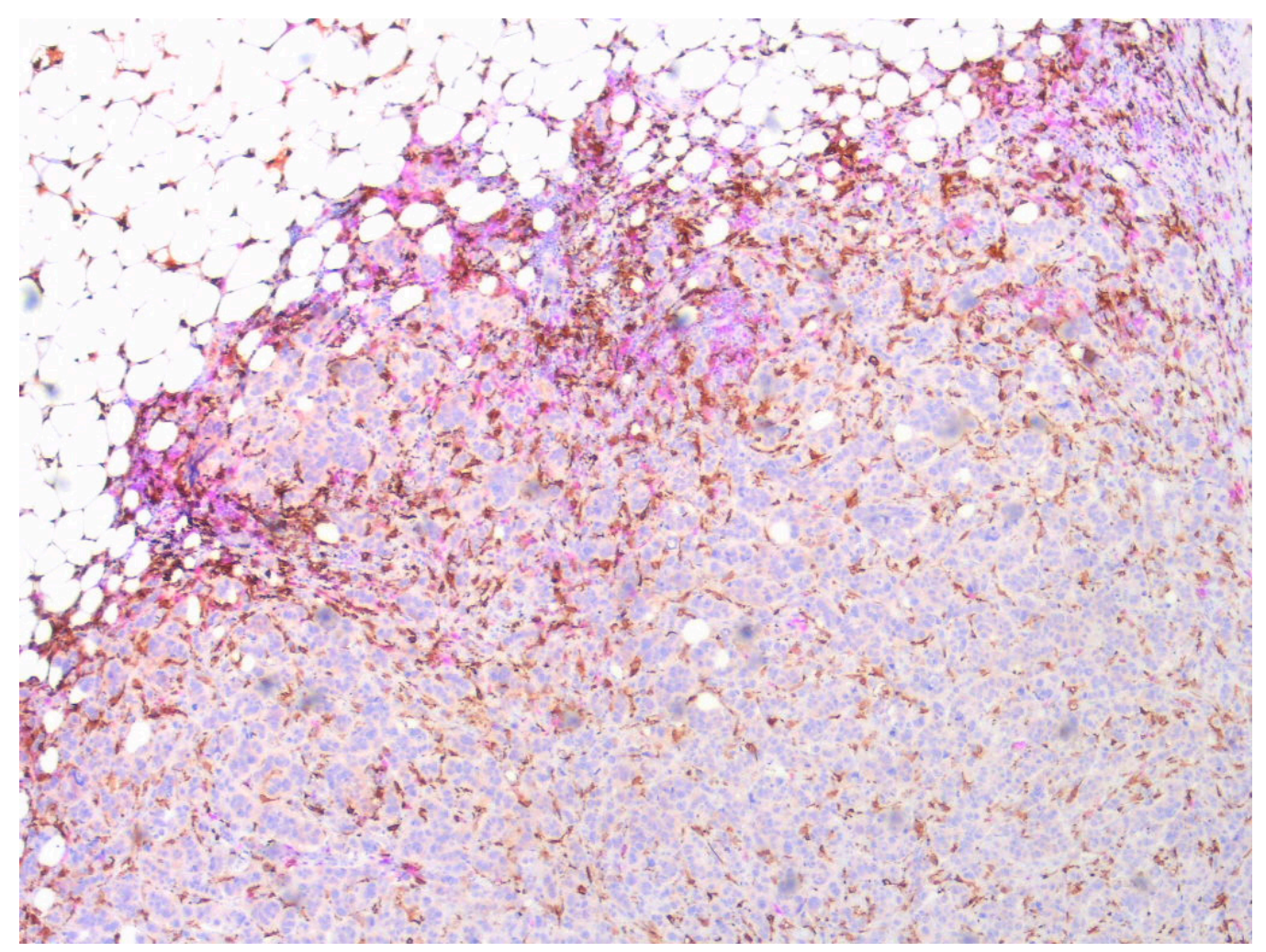

Figure 2. Double staining of a sample of a resected primary breast cancer. CD163-positive monocytes/macrophages visualized by EnVisio FLEX Substrate buffer SM803 (brown) and CCR-positive by AEC10HPP (magenta). Magnification $20 \times$.

\subsection{CNB-Induced Changes in the Expression of CCL2, CCR2, CD163 and CD14}

CCL2, CCR2, CD163 and CD14 showed significantly different levels of expression in the biopsies as compared to the corresponding resected tumors.

CCL2 was expressed in 100\% of the epithelial tumor cells, both in the samples from CNBs and excised tumors, while the level of expression varied. The frequency of strongly positive malignant epithelial cells was higher in the CNBs than in the tumors after biopsy (score 2.2 vs. 1.8, $p=0.001$, Figure 3A,B). Although significant in the entire material, the difference between the CNB and resected tumor was insignificant in low grade, small and PR-negative tumors (Table 2).

Stromal lymphocytes also expressed CCL2. The percentage of CCL2-positive lymphocytes was lower in the CNBs and increased after biopsy (score 0.6 vs. 1.6 in the excised tumors ( $p=0.001$, Figure 3A). The increase of CCL2-positive lymphocytes was independent of the clinicopathological prognostic markers and the age of the patient (Table 2).

\subsection{Expression of CD163, CD14 and CCR2}

CD163 was abundantly expressed at the protein level in both intratumoral and stromal monocytes/macrophages. Both intratumorally and in the stroma, the number of CD163positive monocytes/macrophages was significantly higher in the excised tumors than in the corresponding CNBs. The intratumoral means of the CD163-positive cells per $40 \times$ field of vision were 22.5 in the CNBs and 41.3 in the corresponding excised tumors, and in the stroma, the means were 29.2 and 55.8, respectively. ( $p=0.001$, Figure 4a,b). The difference in the expression between the biopsies and the corresponding resected tumors was independent of the time lapse, histology, tumor-related prognostic parameters and the age of the patient, with the exception of the PR-negative tumors, where the intratumoral increase of the CD163-positive cells did not reach statistical significance (Table 2). 


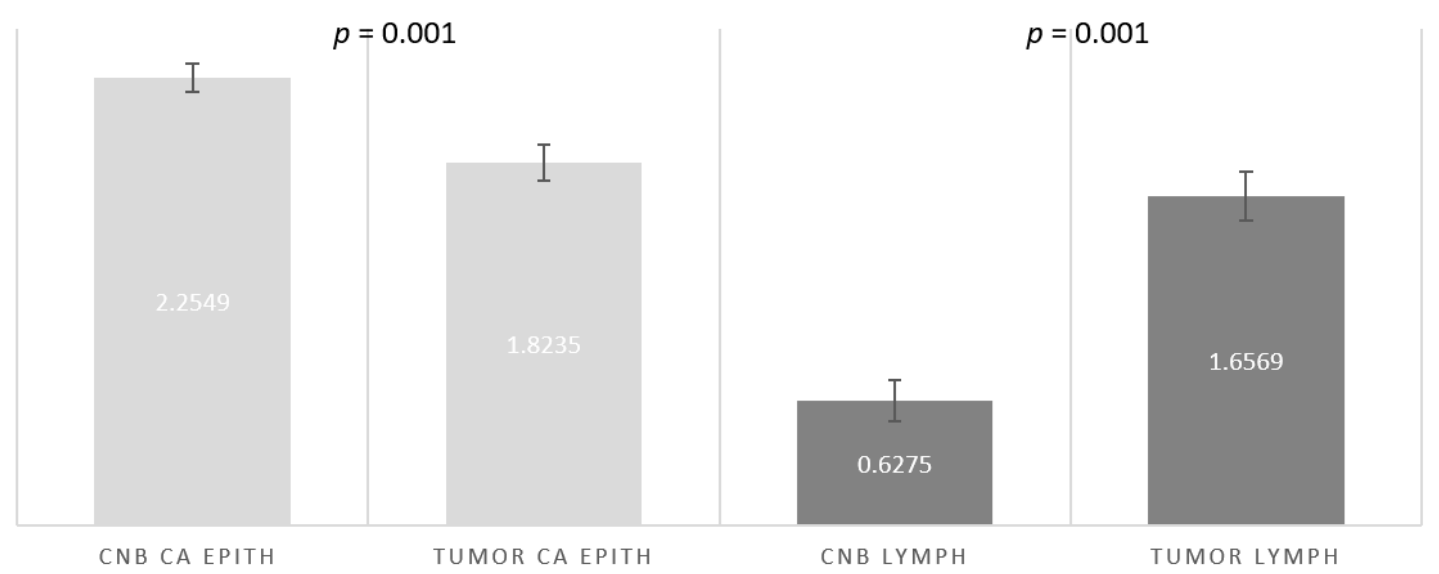

(A)

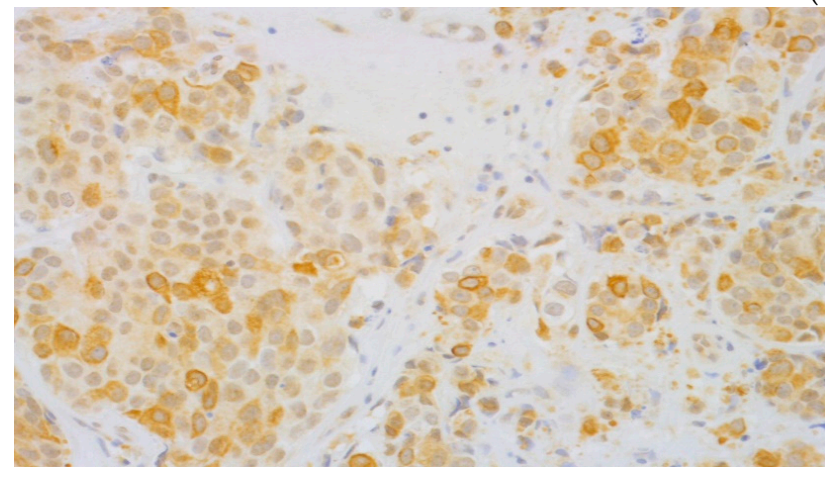

(a)

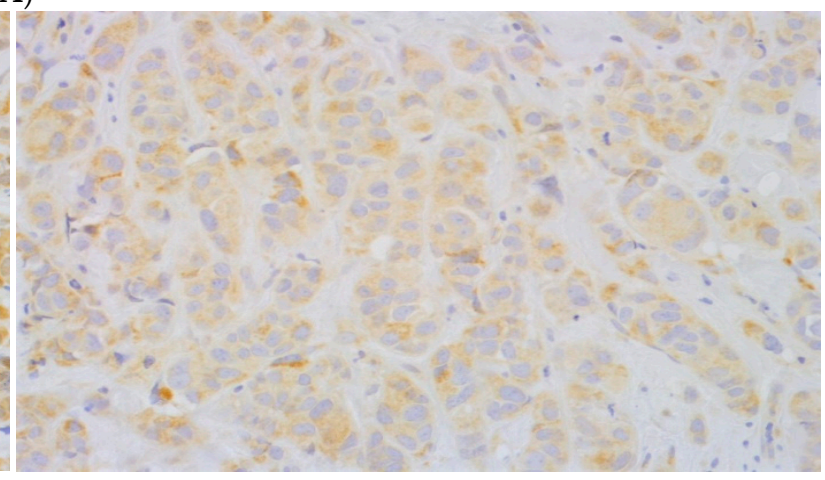

(b)

(B)

Figure 3. (A) The difference in the scored (0-3) percentage of strongly CCL2-positive malignant epithelial cells in samples from CNBs (CNB CA EPITH) vs. the corresponding resected tumors (TUMOR CA EPITH), and the difference in the scored (0-3) percentage of CCL2-positive stromal lymphocytes in CNBs (CNB LYMPH) vs. in the corresponding tumors (TUMOR LYMPH). Paired $t$-test was used. (B) Expression of CCL2 in a malignant epithelium in primary breast cancer: (a) CNB and (b) the corresponding resected tumor magnification $40 \times$.

CD14 was expressed at the protein level in both intratumoral and stromal monocytes/macrophages, although less abundantly than CD163. In both locations, the frequency of CD14-positive cells was higher in the excised tumors than in the biopsies. The intratumoral means of CD14-positive cells per $40 \times$ field of vision were 12.7 in the CNBs and 22.1 in the corresponding excised tumors $(p=0.001)$. The stromal means were 17.8 and 30.2, respectively, $p=0.001$, Figure $4 a, b)$. Intratumorally, the difference between the CNBs and the corresponding resected tumors did not reach statistical significance in the tumors with lobular histology, PR negativity and a low grade. Tumors with a high expression of Ki67 also presented an insignificant increase in intratumoral CD14-positive cells in the tumors. The stromal increase of the CD14-positive cells after a biopsy was independent of time lapse, histology, tumor-related prognostic parameters and the age of the patient (Table 2).

CCR2 was expressed in monocytes/macrophages located in the surrounding stroma, whereas the intratumoral monocytes were less often positive for CCR2. The number of positive monocytes in the peripheral stroma was significantly higher in the excised tumors than in the corresponding CNBs (mean of the positive cells per $40 \times$ view in the CNBs was 13.6 and, in excised tumors, 35.8, $p=0.001$, Figure $4 a, b$ ). The difference between CNB and a tumor was independent of the clinicopathological prognostic markers and the age of the 
patient (Table 2). In the intratumoral stroma and in close vicinity of malignant cells, the number of CCR2-positive monocytes was few but slightly more numerous in the resected tumors (mean of the positive cells in $40 \times$ view was 10.4 ) than in the corresponding biopsies (mean 9.8), the difference not being significant (Figure $4 a$ ). In tumors resected $\geq 25$ days after the biopsy was taken, the increase of the CCR2-positive monocytes/macrophages intratumorally in the resected tumors was more pronounced than in the whole set of cases $(p=0.053$, Table 2).

Due to the small size of the cohort, the possible predictive value of the CCL2 gradient at the baseline could not be computed. The expression level of CCL2 in the tumor cells in the biopsies was $\geq$ median in $46 / 52$ samples.

Table 2. Impact of clinicopathological features of the tumors, the biopsy-to-tumor resection delay, and the age of the patient on the biopsy-induced changes in the expression of CCL2, CD14, CD163 and CCR2. The difference in the scored (0-3) percentage of strongly CCL2 positive malignant epithelial cells (CCL tumor) in samples from CNBs (C) vs corresponding resected tumors (T), the difference in the scored (0-3) percentage of CCL2 positive stromal lymphocytes (CCL2 lymph) in CNBs (C) vs. in corresponding tumors $(\mathrm{T})$, and the difference between $\mathrm{CNB}(\mathrm{C})$ vs corresponding resected tumor (T) with regard to the means of CD163, CD14 and CCR2 positive monocytes/macrophages per $40 \times$ view intratumorally (i) and in the stroma (str) in the whole material and, for comparison, in specified subsets are shown. Paired $t$-test was used ( $p=p$-value) $\mathrm{N}=$ number of cases.

\begin{tabular}{|c|c|c|c|c|c|c|c|c|c|c|c|c|}
\hline \multicolumn{13}{|c|}{ Nodal Involvement; Node Negative $=n-$, Node Positive $=n+$} \\
\hline & $\begin{array}{c}\text { All } \\
\mathbf{N}\end{array}$ & $\mathrm{C}$ & $\mathbf{T}$ & $p$ & $\begin{array}{c}\mathbf{n}- \\
\mathbf{N}\end{array}$ & $\mathrm{C}$ & $\mathrm{T}$ & $p$ & $\begin{array}{c}\mathbf{n}+ \\
\mathbf{N}\end{array}$ & $\mathrm{C}$ & $\mathbf{T}$ & $p$ \\
\hline $\begin{array}{l}\text { CCL2 } \\
\text { tumor }\end{array}$ & 49 & 2.3 & 1.9 & 0.001 & 23 & 2.3 & 1.9 & 0.032 & 26 & 2.3 & 1.8 & 0.006 \\
\hline $\begin{array}{l}\text { CCL2 } \\
\text { lymph }\end{array}$ & 49 & 0.63 & 1.7 & 0.001 & 23 & 0.61 & 1.7 & 0.001 & 26 & 0.65 & 1.7 & 0.001 \\
\hline CD14 i & 49 & 12.7 & 22.1 & 0.001 & 22 & 14.7 & 28.3 & 0.008 & 27 & 11.7 & 18.5 & 0.004 \\
\hline CD14 str & 49 & 17.8 & 30.2 & 0.001 & 22 & 20.9 & 28.9 & 0.004 & 27 & 16.3 & 32.0 & 0.001 \\
\hline CD163 i & 50 & 22.5 & 41.3 & 0.001 & 23 & 23.5 & 44.6 & 0.001 & 27 & 22.3 & 40.0 & 0.001 \\
\hline CD163 str & 50 & 29.2 & 55.8 & 0.001 & 23 & 32.5 & 54.8 & 0.002 & 27 & 28.0 & 57.8 & 0.001 \\
\hline CCR2 i & 50 & 9.8 & 10.4 & 0.666 & 23 & 8.8 & 9.5 & 0.720 & 27 & 11.3 & 11.7 & 0.807 \\
\hline CCR2 str & 50 & 13.6 & 35.8 & 0.001 & 23 & 15.7 & 37.8 & 0.001 & 27 & 12.5 & 35.2 & 0.001 \\
\hline \multicolumn{13}{|c|}{ Tumor size $<20 \mathrm{~mm}$ vs. $\geq 20 \mathrm{~mm}$} \\
\hline & $\begin{array}{c}\text { All } \\
\mathbf{N}\end{array}$ & $\mathrm{C}$ & $\mathbf{T}$ & $p$ & $<20 \mathrm{~N}$ & $\mathrm{C}$ & $\mathrm{T}$ & $p$ & $\geq 20 \mathrm{~N}$ & $\mathrm{C}$ & $\mathbf{T}$ & $p$ \\
\hline $\begin{array}{l}\text { CCL2 } \\
\text { tumor }\end{array}$ & 51 & 2.3 & 1.8 & 0.001 & 25 & 2.1 & 1.8 & 0.053 & 26 & 2.4 & 1.9 & 0.001 \\
\hline $\begin{array}{l}\text { CCL2 } \\
\text { lymph }\end{array}$ & 51 & 0.63 & 1.7 & 0.001 & 25 & 0.56 & 1.4 & 0.001 & 26 & 0.7 & 1.9 & 0.001 \\
\hline CD14 i & 51 & 12.7 & 22.1 & 0.001 & 25 & 11.3 & 23.2 & 0.003 & 26 & 14.0 & 21.1 & 0.026 \\
\hline CD14 str & 51 & 17.8 & 30.2 & 0.001 & 25 & 17.4 & 29.5 & 0.001 & 26 & 18.3 & 31.0 & 0.001 \\
\hline CD163 i & 52 & 22.5 & 41.3 & 0.001 & 26 & 19.7 & 42.5 & 0.001 & 26 & 25.3 & 40.0 & 0.001 \\
\hline CD163 str & 52 & 29.2 & 55.8 & 0.001 & 26 & 28.2 & 54.4 & 0.001 & 26 & 30.2 & 57.1 & 0.001 \\
\hline CCR2 i & 52 & 9.8 & 10.4 & 0.613 & 26 & 8.7 & 11.5 & 0.139 & 26 & 10.8 & 9.4 & 0.434 \\
\hline CCR2 str & 52 & 13.6 & 35.8 & 0.001 & 26 & 13.5 & 32.7 & 0.001 & 26 & 13.7 & 38.8 & 0.001 \\
\hline
\end{tabular}


Table 2. Cont.

Nodal Involvement; Node Negative $=\mathbf{n}-$, Node Positive $=\mathbf{n}+$

Gradus 1 vs. Gradus 2-3

\begin{tabular}{|c|c|c|c|c|c|c|c|c|c|c|c|c|}
\hline & $\begin{array}{c}\text { All } \\
\mathbf{N}\end{array}$ & $\mathrm{C}$ & $\mathbf{T}$ & $p$ & $\begin{array}{l}\text { G1 } \\
\text { N }\end{array}$ & C & $\mathbf{T}$ & $p$ & $\begin{array}{c}\text { G2-3 } \\
\mathbf{N}\end{array}$ & C & $\mathbf{T}$ & $p$ \\
\hline $\begin{array}{l}\text { CCL2 } \\
\text { tumor }\end{array}$ & 51 & 2.3 & 1.8 & 0.001 & 11 & 2.2 & 2.0 & 0.506 & 40 & 2.3 & 1.8 & 0.001 \\
\hline $\begin{array}{l}\text { CCL2 } \\
\text { lymph }\end{array}$ & 51 & 0.63 & 1.7 & 0.001 & 11 & 0.27 & 1.3 & 0.001 & 40 & 0.73 & 1.8 & 0.001 \\
\hline CD14 i & 51 & 12.7 & 22.1 & 0.001 & 11 & 8.2 & 20.5 & 0.064 & 40 & 13.9 & 22.6 & 0.001 \\
\hline CD14 str & 51 & 17.8 & 30.2 & 0.001 & 11 & 11.8 & 22.5 & 0.020 & 40 & 19.5 & 32.4 & 0.001 \\
\hline CD163 i & 52 & 22.5 & 41.3 & 0.001 & 11 & 17.1 & 35.0 & 0.001 & 41 & 23.1 & 42.9 & 0.001 \\
\hline CD163 str & 52 & 29.2 & 55.8 & 0.001 & 11 & 18.2 & 44.5 & 0.017 & 41 & 32.1 & 58.8 & 0.001 \\
\hline CCR2 i & 52 & 9.8 & 10.4 & 0.613 & 11 & 5.4 & 6.5 & 0.319 & 41 & 11.0 & 11.5 & 0.752 \\
\hline CCR2 str & 52 & 13.6 & 35.8 & 0.001 & 23 & 10.3 & 23.2 & 0.005 & 41 & 14.5 & 39.1 & 0.001 \\
\hline \multicolumn{13}{|c|}{ Ductal vs. Lobular } \\
\hline & $\begin{array}{c}\text { All } \\
\mathrm{N}\end{array}$ & C & $\mathbf{T}$ & $p$ & $\begin{array}{c}\text { Ductal } \\
\mathbf{N}\end{array}$ & $\mathrm{C}$ & $\mathbf{T}$ & $p$ & $\begin{array}{c}\text { Lobular } \\
\mathbf{N}\end{array}$ & C & $\mathbf{T}$ & $p$ \\
\hline $\begin{array}{l}\text { CCL2 } \\
\text { tumor }\end{array}$ & 51 & 2.3 & 1.8 & 0.001 & 28 & 2.2 & 1.7 & 0.010 & 23 & 2.3 & 1.9 & 0.002 \\
\hline $\begin{array}{l}\text { CCL2 } \\
\text { lymph }\end{array}$ & 51 & 0.63 & 1.7 & 0.001 & 28 & 0.79 & 1.8 & 0.001 & 23 & 0.43 & 1.5 & 0.001 \\
\hline CD14 i & 51 & 12.7 & 22.1 & 0.001 & 27 & 12.3 & 24.2 & 0.001 & 24 & 13.0 & 19.8 & 0.055 \\
\hline CD14 str & 51 & 17.8 & 30.2 & 0.001 & 27 & 18.5 & 31.9 & 0.001 & 24 & 17.1 & 28.3 & 0.001 \\
\hline CD163 i & 52 & 22.5 & 41.3 & 0.001 & 28 & 24.4 & 46.3 & 0.001 & 24 & 20.2 & 35.4 & 0.004 \\
\hline CD163 str & 52 & 29.2 & 55.8 & 0.001 & 28 & 32.8 & 61.4 & 0.001 & 24 & 25.0 & 49.2 & 0.001 \\
\hline CCR2 i & 52 & 9.8 & 10.4 & 0.613 & 28 & 11.8 & 11.4 & 0.860 & 24 & 7.5 & 9.3 & 0.238 \\
\hline CCR2 str & 52 & 13.6 & 35.8 & 0.001 & 28 & 16.2 & 39.1 & 0.001 & 24 & 10.6 & 31.9 & 0.001 \\
\hline \multicolumn{13}{|c|}{ Ki67/MIB $<30 \%$ vs. $\geq 30 \%$} \\
\hline & $\begin{array}{c}\text { All } \\
\mathbf{N}\end{array}$ & C & $\mathbf{T}$ & $p$ & $\begin{array}{c}\text { MIBlow } \\
\mathbf{N}\end{array}$ & C & $\mathbf{T}$ & $p$ & $\begin{array}{l}\text { MIBhigh } \\
\mathbf{N}\end{array}$ & $\mathrm{C}$ & $\mathbf{T}$ & $p$ \\
\hline $\begin{array}{l}\text { CCL2 } \\
\text { tumor }\end{array}$ & 51 & 2.3 & 1.8 & 0.001 & 31 & 2.2 & 1.8 & 0.001 & 20 & 2.3 & 1.9 & 0.034 \\
\hline $\begin{array}{l}\text { CCL2 } \\
\text { lymph }\end{array}$ & 51 & 0.63 & 1.7 & 0.001 & 31 & 0.2 & 1.8 & 0.001 & 20 & 0.85 & 1.9 & 0.001 \\
\hline CD14 i & 51 & 12.7 & 22.1 & 0.001 & 31 & 10.4 & 21.8 & 0.001 & 20 & 16.3 & 22.6 & 0.118 \\
\hline CD14 str & 51 & 17.8 & 30.2 & 0.001 & 31 & 14.7 & 25.7 & 0.001 & 20 & 22.8 & 37.3 & 0.001 \\
\hline CD163 i & 52 & 22.5 & 41.3 & 0.001 & 31 & 19.4 & 32.9 & 0.001 & 21 & 27.0 & 53.7 & 0.001 \\
\hline CD163 str & 52 & 29.2 & 55.8 & 0.001 & 31 & 21.1 & 45.2 & 0.001 & 20 & 41.1 & 71.4 & 0.001 \\
\hline CCR2 i & 52 & 9.8 & 10.4 & 0.613 & 31 & 7,2 & 9.6 & 0.052 & 21 & 13.5 & 11.7 & 0.488 \\
\hline CCR2 str & 52 & 13.6 & 35.8 & 0.001 & 31 & 11.2 & 25.8 & 0.001 & 21 & 17.2 & 50.5 & 0.001 \\
\hline
\end{tabular}


Table 2. Cont.

Nodal Involvement; Node Negative $=\mathbf{n}-$, Node Positive $=\mathbf{n}+$

Time lapse from biopsy to tumor resection $<25$ days vs. $\geq 25$ days

\begin{tabular}{|c|c|c|c|c|c|c|c|c|c|c|c|c|}
\hline & $\begin{array}{c}\text { All } \\
\mathbf{N}\end{array}$ & $\mathrm{C}$ & $\mathrm{T}$ & $p$ & $<25 \mathrm{~N}$ & $\mathrm{C}$ & $\mathbf{T}$ & $p$ & $\geq 25 \mathrm{~N}$ & $\mathrm{C}$ & $\mathbf{T}$ & $p$ \\
\hline $\begin{array}{l}\text { CCL2 } \\
\text { tumor }\end{array}$ & 51 & 2.3 & 1.8 & 0.001 & 22 & 2.3 & 1.9 & 0.018 & 29 & 2.2 & 1.7 & 0.003 \\
\hline $\begin{array}{l}\text { CCL2 } \\
\text { lymph }\end{array}$ & 51 & 0.63 & 1.7 & 0.001 & 22 & 0.60 & 1.5 & 0.001 & 29 & 0.66 & 1.7 & 0.001 \\
\hline CD14 i & 51 & 12.7 & 22.1 & 0.001 & 23 & 12.7 & 22.9 & 0.009 & 28 & 12.6 & 21.5 & 0.009 \\
\hline CD14 str & 51 & 17.8 & 30.2 & 0.001 & 23 & 18.0 & 30.7 & 0.001 & 28 & 17.7 & 29.9 & 0.001 \\
\hline CD163 i & 52 & 22.5 & 41.3 & 0.001 & 23 & 21.6 & 42.4 & 0.001 & 29 & 23.1 & 40.3 & 0.001 \\
\hline CD163 str & 52 & 29.2 & 55.8 & 0.001 & 23 & 37.0 & 57.2 & 0.001 & 29 & 23.0 & 54.7 & 0.001 \\
\hline CCR2 i & 52 & 9.8 & 10.4 & 0.613 & 23 & 11.3 & 9.8 & 0.528 & 29 & 8.5 & 10.9 & 0.053 \\
\hline CCR2 str & 52 & 13.6 & 35.8 & 0.001 & 23 & 13.3 & 35.7 & 0.001 & 29 & 13.9 & 35.9 & 0.001 \\
\hline \multicolumn{13}{|c|}{ Age $<50$ year vs. $\geq 50$ year } \\
\hline & $\begin{array}{c}\text { All } \\
\mathbf{N}\end{array}$ & $\mathrm{C}$ & $\mathrm{T}$ & $p$ & $\begin{array}{c}<50 \\
N\end{array}$ & $\mathrm{C}$ & $\mathrm{T}$ & $p$ & $\begin{array}{l}\geq 50 \\
\mathrm{~N}\end{array}$ & $\mathrm{C}$ & $\mathrm{T}$ & $p$ \\
\hline $\begin{array}{l}\text { CCL2 } \\
\text { tumor }\end{array}$ & 51 & 2.3 & 1.8 & 0.001 & 8 & 2.4 & 2.0 & 0.25 & 43 & 2.2 & 1.8 & 0.001 \\
\hline $\begin{array}{l}\text { CCL2 } \\
\text { lymph }\end{array}$ & 51 & 0.63 & 1.7 & 0.001 & 8 & 0.6 & 1.4 & 0.04 & 43 & 0.63 & 1.7 & 0.001 \\
\hline CD14 i & 51 & 12.7 & 22.1 & 0.001 & 9 & 8.3 & 22.6 & 0.06 & 42 & 13.6 & 22.0 & 0.002 \\
\hline CD14 str & 51 & 17.8 & 30.2 & 0.001 & 9 & 13.3 & 27.2 & 0.01 & 42 & 18.8 & 30.9 & 0.001 \\
\hline CD163 i & 52 & 22.5 & 41.3 & 0.001 & 9 & 17.8 & 36.1 & 0.02 & 43 & 23.4 & 42.3 & 0.001 \\
\hline CD163 str & 52 & 29.2 & 55.8 & 0.001 & 9 & 29.4 & 52.8 & 0.004 & 43 & 29.1 & 56.4 & 0.001 \\
\hline CCR2 i & 52 & 9.8 & 10.4 & 0.613 & 9 & 13.1 & 8.4 & 0.385 & 43 & 9.07 & 10.8 & 0.118 \\
\hline CCR2 str & 52 & 13.6 & 35.8 & 0.001 & 9 & 11.4 & 38.3 & 0.003 & 43 & 14.1 & 35.2 & 0.001 \\
\hline
\end{tabular}

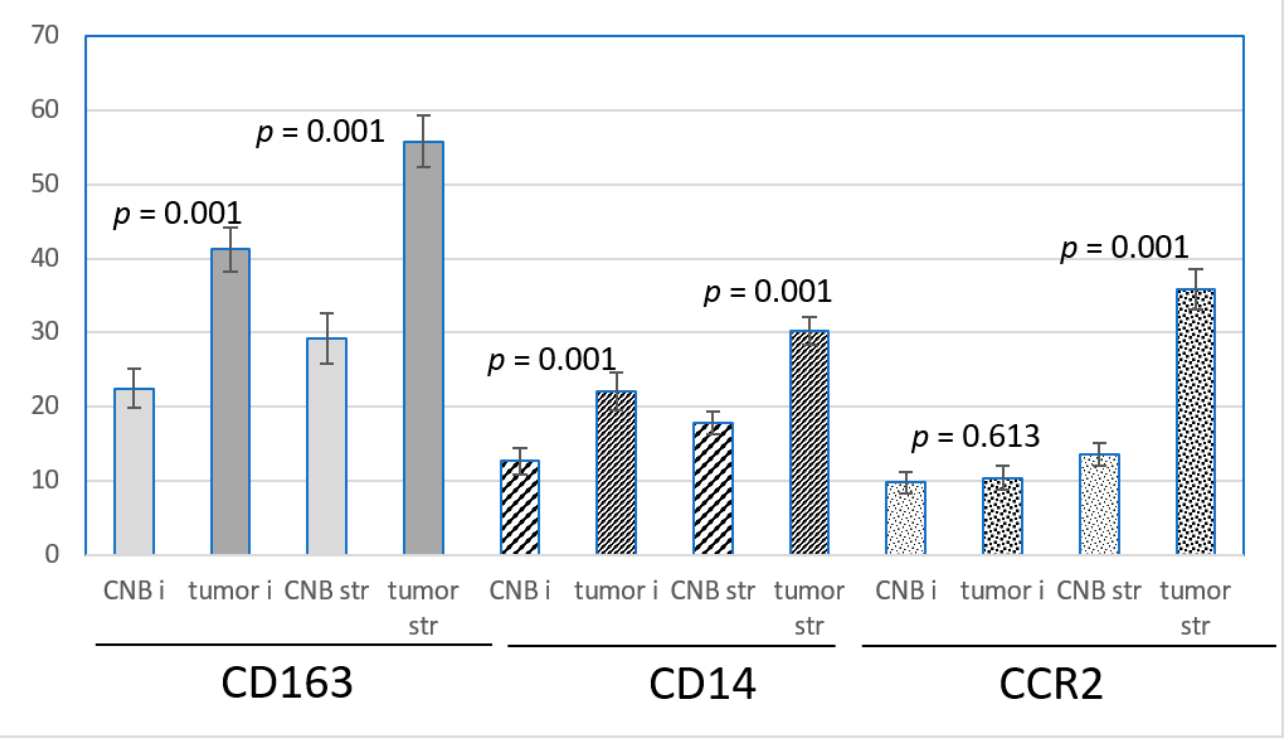

(a)

Figure 4. Cont. 


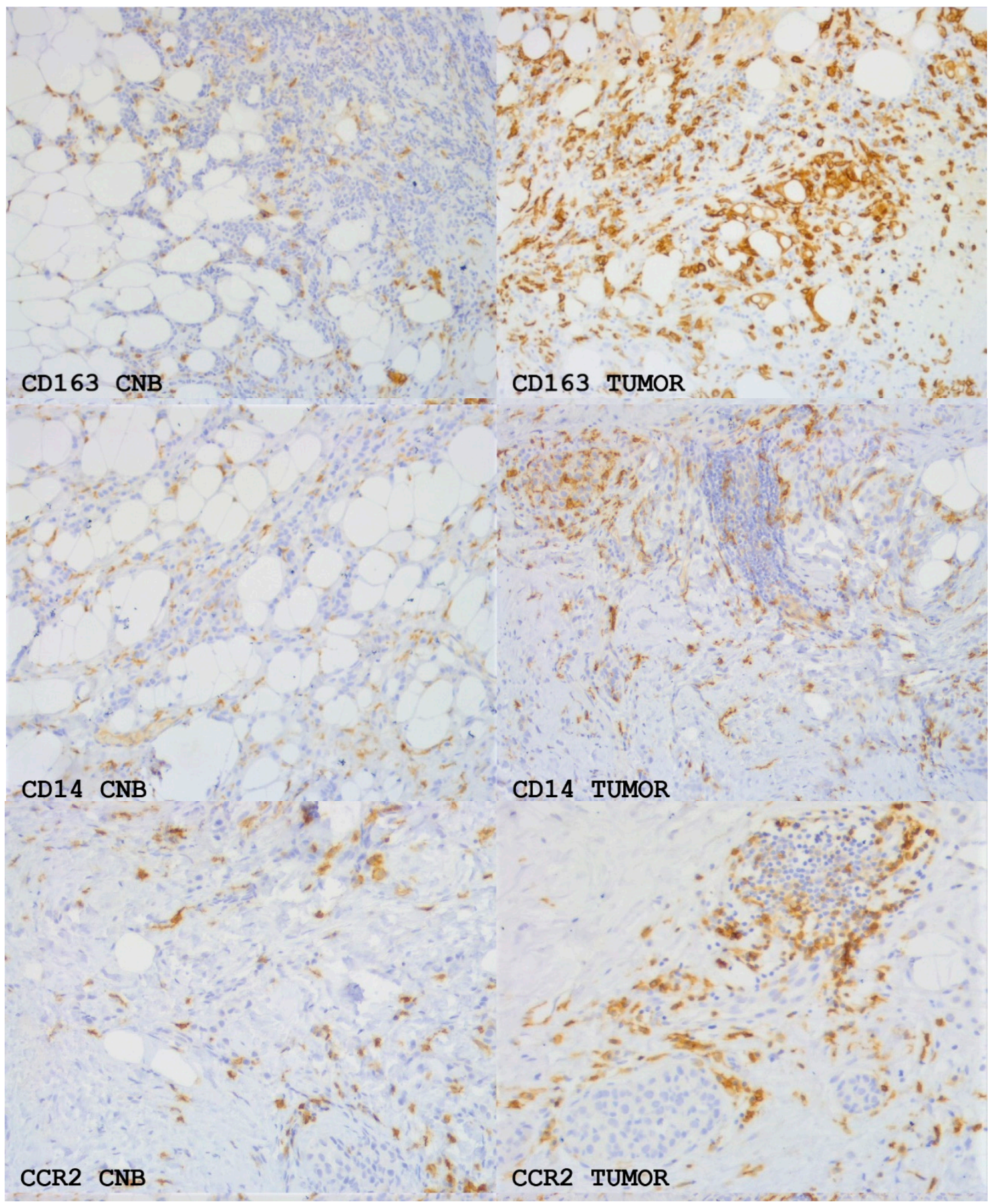

(b)

Figure 4. (a) The means +/- SEM of the number of CD163, CD14 and CCR2-positive monocytes/macrophages per $40 \times$ view intratumorally (i) and in the stroma (str) in samples from CNBs $(\mathrm{CNB})$ and the corresponding resected tumors (tumor). Difference between CNB vs. the corresponding resected tumor is shown. Paired $t$-test was used. (b) CD163, CD14 and CCR2 expression in primary breast cancer in CNBs and corresponding resected tumors. Magnification $20 \times$.

3.5. Correlation of the CCL2/CCR2 Pathway Marker Expression with Clinicopathologic Parameters of the Tumors

The CCL2 expression in stromal lymphocytes correlated positively with the size of the resected tumor $(p=0.027)$ and with the high expression of Ki67 $(p=0.048)$. In the biopsies, the expression level was independent on the prognostic markers (Table 3). 
Table 3. Correlation of the clinicopathological parameters with the expression of CCL2, CCR2, CD163 and CD14 in samples from CNBs, and the corresponding tumors of 52 patients with primary breast cancer. Only statistically significant results are shown. Categorical Pearson's chi-square test was used.

\begin{tabular}{|c|c|c|c|}
\hline & & & $p$-Value \\
\hline & node - & node + & \\
\hline CD163 CNB i low & $7(30.4 \%)$ & $16(69.0 \%)$ & \\
\hline \multirow[t]{2}{*}{ CD163 CNB i high } & $16(59.3 \%)$ & $11(40.7 \%)$ & 0.042 \\
\hline & tumor size $<20 \mathrm{~mm}$ & tumor size $\geq 20 \mathrm{~mm}$ & \\
\hline $\begin{array}{l}\text { CCL2 stromal } \\
\text { lymphocytes low }\end{array}$ & $17(64.5 \%)$ & $9(34.6 \%)$ & \\
\hline \multirow[t]{2}{*}{$\begin{array}{c}\text { CCL2 atromal } \\
\text { lymphocytes high }\end{array}$} & $9(34.6 \%)$ & $17(65.4 \%)$ & 0.027 \\
\hline & tumor grade 1 & tumor grade $2-3$ & \\
\hline CD163 CNB str low & $8(34.8 \%)$ & $15(65.2 \%)$ & \\
\hline CD163 CNB str high & $3(10.3 \%)$ & $26(89.7 \%)$ & 0.032 \\
\hline CD14 tumor str low & $7(38.9 \%)$ & $11(61.1 \%)$ & \\
\hline \multirow[t]{2}{*}{ CD14 tumor str high } & $4(11.8 \%)$ & $30(88.2 \%)$ & 0.023 \\
\hline & duktal & lobular & \\
\hline CCR2 CNB str low & $6(31,6 \%)$ & $13(68.4 \%)$ & \\
\hline CCR2 CNB str high & $19(63.3 \%)$ & $11(36.7 \%)$ & 0.030 \\
\hline CD163 tumor i low & $6(28.6 \%)$ & $15(71.4 \%)$ & \\
\hline CD163 tumor i high & $19(67.9 \%)$ & $9(32.1 \%)$ & 0.006 \\
\hline CD163 tumor str low & $7(33.3 \%)$ & $14(66.7 \%)$ & \\
\hline \multirow[t]{2}{*}{ CD163 tumor str high } & $18(64.3 \%)$ & $10(35.7 \%)$ & 0.032 \\
\hline & Ki67 $<30 \%$ & $\mathrm{Ki} 67 \geq 30 \%$ & \\
\hline $\begin{array}{c}\text { CCL2 stromal } \\
\text { lymphocytes low }\end{array}$ & $19(73.1 \%)$ & $7(26.9 \%)$ & \\
\hline $\begin{array}{c}\text { CCL2 stromal } \\
\text { lymphocytes high }\end{array}$ & $12(46.2 \%)$ & $14(53.8 \%)$ & 0.048 \\
\hline CCR2 CNB str low & $21(87.5 \%)$ & $3(12.5 \%)$ & \\
\hline CCR2 CNB str high & $10(35.7 \%)$ & $18(64.3 \%)$ & 0.001 \\
\hline CD163 tumor i low & $19(79.2 \%)$ & $5(20.8 \%)$ & \\
\hline CD163 tumor i high & $12(42.9 \%)$ & $16(57.1 \%)$ & 0.008 \\
\hline CD163 tumor str low & $19(79.2 \%)$ & $5(20.9 \%)$ & \\
\hline CD163 tumor str high & $12(49.2 \%)$ & $16(57.1 \%)$ & 0.008 \\
\hline CD14 CNB i low & $11(91.7 \%)$ & $1(8.3 \%)$ & \\
\hline \multirow[t]{2}{*}{ CD14 CNB i high } & $20(51.3 \%)$ & $19(48.7 \%)$ & 0.012 \\
\hline & PR - & PR + & \\
\hline CCR2 CNB str low & $1(4.8 \%)$ & $20(95.2 \%)$ & \\
\hline CCR2 CNB str high & $9(29.0 \%)$ & $22(71.0 \%)$ & 0.029 \\
\hline CCR2 tumor str low & $1(4.2 \%)$ & $23(95.8 \%)$ & \\
\hline CCR2 tumor str high & $9(32.1 \%)$ & $19(67.9 \%)$ & 0.011 \\
\hline
\end{tabular}

$\mathrm{CNB}$ = core needle biopsy tumor; $\mathrm{i}$ = intratumoral stroma; str = peripheral stroma.

In the biopsies, DC163-positive cells were intratumorally more abundant in nodenegative vs. node-positive tumors $(p=0.042)$, in ductal vs. lobular tumors $(p=0.029)$ and 
in tumors with a high vs. low expression of $\operatorname{Ki} 67(p=0.008)$. In the peripheral stroma, a high frequency of CD163-positive cells was associated with a high grade of the tumor $(p=0.032)$.

In the resected tumors, CD163-positive cells were more abundant in the intratumoral stroma in the ductal than the lobular tumors $(p=0.032)$ and in tumors with a high Ki67 expression $(p=0.008)$. In the peripheral stroma, CD163-positive cells were more abundant in the tumors with ductal histology $(p=0.032)$ and with a high expression of Ki67 $(p=0.008)$ (Table 3).

The number of intratumoral CD14-positive cells was high in CNBs with a high expression of Ki67 ( $p=0.012)$ and in resected tumors of high grade (2 to 3$)(p=0.023)$ (Table 3$)$.

The expression level of CCR2 was more abundant in the stroma of the biopsies from tumors with a high Ki67 expression $(p=0.012)$ and those negative for PR $(p=0.029)$. In the resected tumors, negative PR was associated with a high number of CCR2-positive myeloid suppressive cells in the stroma $(p=0.011)$ (Table 3$)$.

\section{Discussion}

\subsection{Aims of the Study}

Cancer has been shown to reprogram the myelopoiesis and to facilitate the proliferation of an immature myeloid cell population [17]. The CCL2/CCR2 pathway has emerged as a critical player, especially in breast cancer, in the recruitment of circulating myeloid-derived suppressor cells (MDSC) in tumor sites [18]. Cancer induction and progression involve the development of a tumor-supporting microenvironment with infiltrating myeloid immune cells, increased angiogenesis and an accumulation of fibroblasts. These components are characteristic of inflammation as well. Needle biopsy represents an inflammation-inducing trauma in the tumor and may potentially change the immunological balance between the host and the tumor. The impact of a biopsy on primary breast cancer tissue has not previously been investigated in humans. In an experimental study, tumors from biopsied mice were shown to contain an increased frequency of myeloid-derived suppressor cells (MDSCs) accompanied by a reduced number of CD4+ T cells and CD8+ T, as compared to tumors excised without core needle sampling. Epithelial-mesenchymal transition-related genes were also upregulated after the biopsy [13]. In the current study, we compared samples from core needle biopsies from primary breast cancers to those from the corresponding tumors excised 8-82 days after the biopsy to evaluate the differences CNB may induce in the tumor microenvironment. We focused on the activity of the CCL2/CCR2 pathway and on the infiltration of CCR2, CD163 and CD14-positive monocytes/macrophages, known to be recruited via the CCL2 gradient.

\subsection{Expression of CCL2}

The expression of CCL2 was uniform in our study: all malignant epithelial cells in the CNBs and resected tumors were stained positively. A high expression of CCL2 in the tumors was shown to correlate with a poor prognosis $[19,20]$. We found a fraction of stromal lymphocytes also expressing CCL2, which is in accordance with previous reports of CCL2 being produced not only by tumor cells themselves but also by stromal cells in response to various inflammatory stimuli [21-24]. We found the number of highly CCL2 positive cancer cells higher in the CNBs, while the fraction of CCL2-positive lymphocytes was significantly higher in post-biopsy resected tumors. These changes are supposedly due to the trauma-induced inflammation in cancer stroma, rebalancing the transcriptional control of the expression of CCL2 from tumor cell-mediated mTORC1-regulated towards inflammation-mediated nuclear factor (NF) kB-dependent adjustment $[25,26]$. According to previous data, the downstream effects of a change in the expression of CCL2 modify the host's immune response to the malignancy widely and tumor developmental status dependently: experimental works in breast cancer have suggested that CCL2 facilitates the immunosurveillance of small neoplastic lesions and promotes the growth of neoplastic lesions that have reached a certain critical status [27]. CCL2 directs context-dependently 
and according to the availability of CCR2 the M1-M2 polarization of macrophages $[28,29]$ and divides its effects into peripheral and a tumor-specific components. The biopsyinduced changes in the expression pattern of CCL2 in the tumors shown in our study may mark a point of progression in the developmental status of the tumors. This important signal warrants confirmation in a larger study where different types of tumors can be separately analyzed and the possible intratumoral heterogeneity-induced sampling bias can be addressed.

\subsection{Infiltration of CD163, CD14 and CCR2-Positive Monocytes/Macrophages}

CCL2 regulates the recruitment of myeloid suppressor cells mainly by signaling to CCR2 receptors [30,31]. Macrophages present during the late stage of repair predominantly have an M2 gene expression profile (i.e., IL-10, CD163 and CD206) [32], whereas early invading monocytes in cancer sites are CCR2-positive [33]. CD163 and CCR2-positive cells represent two partially overlapping subsets with different phases of development in the tumor microenvironment. Accordingly, in our study, CCR2 and CD163-positive cells differed in numbers and in location, CCR2-positive cells primarily occupying the peripheral stroma of the tumor and CD163 expressing cells being found both in the stroma and also in the vicinity of the tumor cells. The frequency of CCR2 and CD163-positive monocytes/macrophages in both locations was higher in the excised tumors than in the corresponding biopsies. The appearance of a high number of CCR2-positive cells in the tumors surrounding stroma after biopsy was notable and seemingly reflects the change in the CCL2 gradient, recruiting immature myeloid-suppressive cells to the site. After local proliferation and maturation, these cells become tumor-associated macrophages (TAMs), with a tumor-supporting role [34]. In the same way, CD14-positive immature myeloid cells infiltrate tissues along the CCL2 gradient. Patients with breast cancer have been reported to have higher numbers of circulating monocytes with an altered surface marker expression CD14+ HLA-DR - / low compared with healthy individuals [35]. These immature monocytes have been reported to induce a systemic immunosuppression by inhibiting T-cell proliferation and dendritic cell maturation [36]. Their cell count has been suggested to serve as a surrogate of CCL2/CCR2 pathway activation [37]. In our study, CD14 positive monocytes/macrophages were found both in the stroma and intratumorally in biopsies and resected tumors, although less abundantly than CD163-positive cells. Their numbers increased after biopsy in both locations. The significant post-biopsy increase in the CD14-positive cell count in the tumor tissues reflects a CNB-induced acceleration of the activity of the CCL2/CCR2 axis. According to the previous data, this may worsen the prognostic expectation.

\subsection{Impact of Clinicopathological Prognostic Markers on CNB-Induced Activation of the} CCL2/CCR2 Axis

The CNB-induced increase in the activation level of the CCL2/CCR2 axis in tumors was largely independent on of time lapse, histology and tumor-related prognostic parameters, although the association of the CCL2/CCR2 pathway components with previously known adverse prognostic signs was recapitulated [38-43].

Small and less aggressive tumors had a tendency of slightly smaller increases in the intratumoral infiltration of CD163, CD14 and CCR2-positive monocytes/macrophages as compared to the undivided materials, probably due to a lower developmental status of these tumors. PR-negative tumors showed less pronounced increases in the CD163 and CD14-positive monocytes/macrophages intratumorally, which seems to be based on the high expression of CD163 and CD14 in this location already in the biopsies. PR-negative tumors may represent a subset where the immune response differs from that of the more common types of breast cancer. A larger study on this tumor category is warranted. ERnegative and HER2-positive tumors were not sufficiently represented in our materials, and the possible specificity in the response to CNB in these categories also remains to be resolved. An internal analysis showed that the increase of the expression of all the markers 
after biopsy was independent on the expression level in the CNB (data not shown). Based on this small cohort, a possible predictive value of the activation level of the CCL2/CCR2 pathway in CNBs on biopsy-induced changes cannot be definitively excluded.

\subsection{Future Directions}

The recent quick development of the field of tumor immunology has highlighted the impact of the host's immune system in the prognosis of cancer. The CCL2/CCR2 pathway is emerging as one of the critical components of tumor development and progression $[44,45]$. Interventions aiming at inhibiting the pathway and/or the downstream events are being explored. Deleting CCL2/CCR2 signaling has been shown to suppress the recruitment of macrophages and to decrease the growth, survival and invasion of breast tumor xenografts $[33,46]$. It has been estimated that blocking the CCL2/CCR2 axis could reduce the overall incidence of tumors by preventing TAM recruitment and, therefore, enhancing the antitumor efficacy of CD8+ T cells [47]. Numerous protein-, antibody- and small molecule-based antagonists of the CCL2/CCR2 pathway are being tested [48-50], and less specific macrophage-depleting and innate immune response-activating treatments are being developed [48,51-54]. The results of our study in breast cancer support the previous data and provide a new aspect in the evolving picture. A larger study to confirm the results in different types of tumors and to investigate the downstream effects of the activation of the CCL2/CCR2 pathway, such as the quantity and quality of tumor-infiltrating lymphocytes, is needed. Our findings provide a signal suggesting that attenuating the CCL2/CCR2 axis very early in breast cancer care might maximize the improvement of the prognosis. Increasing the use of neo-adjuvant therapy is likely to partially answer this need, many of the regimens being highly immunomodulatory [55].

\section{Conclusions}

In conclusion, our study showed an early activation of the CCL2/CCR2 pathway in primary breast cancer and a significant tumor type and stage-independent increase in the activity after CNB, marked by an acceleration of the infiltration of CD163, CD14 and CCR2-positive monocytes/macrophages. Our data suggest that CNB has a role in the development of the tumor microenvironment by switching the transcriptional regulation of CCL2 expression. This preliminary pilot work gives an important signal, although, due to the heterogeneity and small size of the cohort, further investigation is needed to confirm this result. Given the dual effect of the CCL2/CCR2 axis in tumor progression, an impact on the peripheral immune machinery is possible, further increasing the importance of a better understanding of the tumor microenvironmental changes a biopsy can induce. Early interventions to attenuate the activity of the CCL2/CCR2 axis may be warranted.

Author Contributions: Data curation, K.J. Project administration, P.H. Writing—original draft, M.H. All authors have read and agreed to the published version of the manuscript.

Funding: This research was funded by Helsinki University Central Hospital Research Foundation grant number M780021041.

Institutional Review Board Statement: This study was conducted according to the guidelines of the Declaration of Helsinki and approved by the Ethics Committee of the Hospital District of Helsinki and Uusimaa (HUS/861/2020). The protocol code is M780021041 and the date of approval 17 June 2020.

Informed Consent Statement: The Ethical Committee of the University of Helsinki did not require informed consents because the study was retrospective and only archived number coded tissue blocks and pathology reports were used. The patients were not recognizable and their clinical data was not included.

Data Availability Statement: The data presented in this study are available on request from the corresponding author.

Conflicts of Interest: The authors declare no conflict of interest. 


\section{References}

1. Kasraeian, S.; Allison, D.C.; Ahlmann, E.R.; Fedenko, A.N.; Menendez, L.R. A Comparison of Fine-needle Aspiration, Core Biopsy, and Surgical Biopsy in the Diagnosis of Extremity Soft Tissue Masses. Clin. Orthop. Relat. Res. 2010, 468, 2992-3002. [CrossRef] [PubMed]

2. Berg, J.W.; Robbins, A.G. A late look at the safety of aspiration biopsy. Cancer 1962, 15, 826-827. [CrossRef]

3. Liikanen, J.; Leidenius, M.; Joensuu, H.; Vironen, J.; Heikkilä, P.; Meretoja, T. Breast cancer prognosis and isolated tumor cell findings in axillary lymph nodes after core needle biopsy and fine needle aspiration cytology: Biopsy method and breast cancer outcome. Eur. J. Surg. Oncol. 2016, 42, 64-70. [CrossRef]

4. Engzell, U.; Zajicek, J. Aspiration biopsy of tumors of the neck. I. Aspiration biopsy and cytologic findings in 100 cases of congenital cysts. Acta Cytol. 1970, 14, 51-57.

5. Uematsu, T.; Kasami, M. Risk of needle tract seeding of breast cancer: Cytological results derived from core wash material. Breast Cancer Res. Treat. 2007, 110, 51-55. [CrossRef]

6. Hu, X.; Chow, L.W. Fine Needle Aspiration May Shed Breast Cells into Peripheral Blood as Determined by RT-PCR. Oncology 2000, 59, 217-222. [CrossRef] [PubMed]

7. Hansen, N.M.; Ye, X.; Grube, B.J.; Giuliano, A.E. Manipulation of the Primary Breast Tumor and the Incidence of Sentinel Node Metastases From Invasive Breast Cancer. Arch. Surg. 2004, 139, 634-640. [CrossRef]

8. Sennerstam, R.B.; Franzén, B.S.H.; Wiksell, H.O.T.; Auer, G.U. Core-needle biopsy of breast cancer is associated with a higher rate of distant metastases 5 to 15 years after diagnosis than FNA biopsy. Cancer Cytopathol. 2017, 125, 748-756. [CrossRef]

9. Chagpar, A.B.; Scoggins, C.R.; Sahoo, S.; Martin, R.C.; Carlson, D.J.; Laidley, A.L.; El-Eid, S.E.; McGlothin, T.Q.; Noyes, R.D.; Ley, P.B.; et al. Biopsy type does not influence sentinel lymph node status. Am. J. Surg. 2005, 190, 551-556. [CrossRef]

10. Liebens, F.; Carly, B.; Cusumano, P.; Van Beveren, M.; Beier, B.; Fastrez, M.; Rozenberg, S. Breast cancer seeding associated with core needle biopsies: A systematic review. Maturitas 2009, 62, 113-123. [CrossRef]

11. Loughran, C.F.; Keeling, C.R. Seeding of tumour cells following breast biopsy: A literature review. Br. J. Radiol. 2011, 84, 869-874. [CrossRef]

12. Shyamala, K.; Girish, H.C.; Murgod, S. Risk of tumor cell seeding through biopsy and aspiration cytology. J. Int. Soc. Prev. Community Dent. 2014, 4, 5-11. [CrossRef]

13. Mathenge, E.G.; Dean, C.A.; Clements, D.; Vaghar-Kashani, A.; Photopoulos, S.; Coyle, K.M.; Giacomantonio, M.; Malueth, B.; Nunokawa, A.; Jordan, J.; et al. Core needle biopsy of breast cancer tumors increases distant metastases in a mouse model. Neoplasia 2014, 16, 950-960. [CrossRef] [PubMed]

14. Heiskala, M.; Leidenius, M.; Joensuu, K.; Heikkilä, P. High expression of CCL2 in tumor cells and abundant infiltration with CD14 positive macrophages predict early relapse in breast cancer. Virchows Arch. 2019, 474, 3-12. [CrossRef]

15. Yang, J.; Zhang, L.; Yu, C.; Yang, X.-F.; Wang, H. Monocyte and macrophage differentiation: Circulation inflammatory monocyte as biomarker for inflammatory diseases. Biomark. Res. 2014, 2, 1. [CrossRef]

16. Yao, M.; Fang, W.; Smart, C.; Hu, Q.; Huang, S.; Alvarez, N.; Fields, P.; Cheng, N. CCR2 Chemokine Receptors Enhance Growth and Cell-Cycle Progression of Breast Cancer Cells through SRC and PKC Activation. Mol. Cancer Res. 2018, 17, 604-617. [CrossRef]

17. Messmer, M.; Netherby, C.S.; Banik, D.; Abrams, S.I. Tumor-induced myeloid dysfunction and its implications for cancer immunotherapy. Cancer Immunol. Immunother. 2014, 64, 1-13. [CrossRef] [PubMed]

18. Fang, W.B.; Jokar, I.; Zou, A.; Lambert, D.; Dendukuri, P.; Cheng, N. CCL2/CCR2 Chemokine Signaling Coordinates Survival and Motility of Breast Cancer Cells through Smad3 Protein- and p42/44 Mitogen-activated Protein Kinase (MAPK)-dependent Mechanisms. J. Biol. Chem. 2012, 287, 36593-36608. [CrossRef]

19. Li, X.; Yao, W.; Yuan, Y.; Chen, P.; Li, B.; Li, J.; Chu, R.; Song, H.; Xiel, D.; Jiang, X.; et al. Targeting of tumourinfiltrating macrophages via CCL2/CCR2 signalling as a therapeutic strategy against hepatocellular carcinoma. Gut 2017, 66, 157-167. [CrossRef] [PubMed]

20. Ueno, T.; Toi, M.; Saji, H.; Muta, M.; Bando, H.; Kuroi, K.; Koike, M.; Inadera, H.; Matsushima, K. Significance of macrophage chemoattractant protein-1 in macrophage recruitment, angiogenesis, and survival in human breast cancer. Clin. Cancer Res. 2000, 6, 3282-3289.

21. Owen, J.L.; Lopez, D.M.; Grosso, J.F.; Guthrie, K.M.; Herbert, L.M.; Torroella-Kouri, M.; Iragavarapu-Charyulu, V. The expression of CCL2 by T lymphocytes of mammary tumor bearers: Role of tumor-derived factors. Cell. Immunol. 2005, 235, 122-135. [CrossRef]

22. Hao, Q.; Vadgama, J.V.; Wang, P. CCL2/CCR2 signaling in cancer pathogenesis. Cell Commun. Signal. 2020, 18, 82. [CrossRef] [PubMed]

23. Yoshimura, T. The chemokine MCP-1 (CCL2) in the host interaction with cancer: A foe or ally? Cell and Mol. Immunology 2018, 15, 335-345. [CrossRef]

24. Bussard, K.M.; Mutkus, L.; Strumpf, K.; Comez-Manzano, C.; Marini, F.C. Tumor-associated stromal cells as key contributors to the tumor microenvironment. Breast Cancer Res. 2016, 18, 84. [CrossRef]

25. Deng, X.; Xu, M.; Yuan, C.; Yin, L.; Chen, X.; Zhou, X.; Li, G.; Fu, Y.; Feghali-Bostwick, C.A.; Pang, L. Transcriptional regulation of increased CCL2 expression in pulmonary fibrosis involves nuclear factor- $\mathrm{KB}$ and activator protein-1. Int. J. Biochem. Cell Biol. 2013, 45, 1366-1376. [CrossRef] [PubMed]

26. Nakatsumi, H.; Matsumoto, M.; Nakayama, K.I. Noncanonical Pathway for Regulation of CCL2 Expression by an mTORC1FOXK1 Axis Promotes Recruitment of Tumor-Associated Macrophages. Cell Rep. 2017, 21, 2471-2486. [CrossRef] [PubMed] 
27. Li, M.; A Knight, D.; A Snyder, L.; Smyth, M.J.; Stewart, T.J. A role for CCL2 in both tumor progression and immunosurveillance. OncoImmunology 2013, 2, e25474. [CrossRef] [PubMed]

28. Gschwandtner, M.; Derler, R.; Midwood, K.S. More Than Just Attractive: How CCL2 Influences Myeloid Cell Behavior Beyond Chemotaxis. Front. Immunol. 2019, 10, 2759. [CrossRef]

29. Zhao, B.N.; Campbell, J.J.; Salanga, C.L.; Ertl, L.S.; Wang, Y.; Yau, S.; Dang, T.; Zeng, Y.; McMahon, J.P.; Krasinski, A.; et al. CCR2-Mediated Uptake of Constitutively Produced CCL2: A Mechanism for Regulating Chemokine Levels in the Blood. J. Immunol. 2019, 203, 3157-3165. [CrossRef]

30. Yao, M.; Brummer, G.; Acevedo, D.; Cheng, N. Cytokine Regulation of Metastasis and Tumorigenicity. Adv. Cancer Res. 2016, 132, 265-367. [CrossRef]

31. O'Connor, T.; Borsig, L.; Heikenwalder, M. CCL2-CCR2 signaling in disease pathogenesis. Endocr. Metab. Immune Disord. Drug Targets 2015, 15, 105-118. [CrossRef]

32. Willenborg, S.; Lucas, T.; Van Loo, G.; Knipper, J.; Krieg, T.; Haase, I.; Brachvogel, B.; Hammerschmidt, M.; Nagy, A.; Ferrara, N.; et al. CCR2 recruits an inflammatory macrophage subpopulation critical for angiogenesis in tissue repair. Blood 2012, 120, 613-625. [CrossRef] [PubMed]

33. Qian, B.-Z.; Li, J.; Zhang, H.; Kitamura, T.; Zhang, J.; Campion, L.R.; Kaiser, E.A.; Snyder, L.A.; Pollard, J.W. CCL2 recruits inflammatory monocytes to facilitate breast-tumour metastasis. Nature 2011, 475, 222-225. [CrossRef]

34. Franklin, R.A.; Liao, W.; Sarkar, A.; Kim, M.V.; Bivona, M.R.; Liu, K.; Pamer, E.G.; Li, M.O. The cellular and molecular origin of tumor-associated macrophages. Science 2014, 344, 921-925. [CrossRef] [PubMed]

35. Speigl, L.; Burow, H.; Bailur, J.K.; Janssen, N.; Walter, C.-B.; Pawelec, G.; Shipp, C. CD14+ HLA-DR-/low MDSCs are elevated in the periphery of early-stage breast cancer patients and suppress autologous T cell proliferation. Breast Cancer Res. Treat. 2018, 168, 401-411. [CrossRef] [PubMed]

36. Laborde, R.R.; Elin, Y.; Gustafson, M.P.; Bulur, P.A.; Dietz, A.B. Cancer Vaccines in the World of Immune Suppressive Monocytes (CD14+HLA-DRlo/neg Cells): The Gateway to Improved Responses. Front. Immunol. 2014, 5, 147. [CrossRef]

37. Shi, C.; Pamer, E.G. Monocyte recruitment during infection and inflammation. Nat. Rev. Immunol. 2011, 11, 762-774. [CrossRef]

38. Inwald, E.C.; Klinkhammer-Schalke, M.; Hofstädter, F.; Zeman, F.; Koller, M.; Gerstenhauer, M.; Ortmann, O. Ki-67 is a prognostic parameter in breast cancer patients: Results of a large population-based cohort of a cancer registry. Breast Cancer Res. Treat. 2013, 139, 539-552. [CrossRef]

39. Tabar, L.; Fagerberg, G.; Chen, H.H.; Duffy, S.W.; Gad, A. Tumour development, histology and grade of breast cancers: Prognosis and progression. Int. J. Cancer 1996, 66, 413-419. [CrossRef]

40. Patani, N.; Martin, L.-A.; Dowsett, M. Biomarkers for the clinical management of breast cancer: International perspective. Int. J. Cancer 2012, 133, 1-13. [CrossRef]

41. Hammond, M.E.H.; Hayes, D.F.; Dowsett, M.; Allred, D.C.; Hagerty, K.L.; Badve, S.; Fitzgibbons, P.L.; Francis, G.; Goldstein, N.S.; Hayes, M.; et al. American Society of Clinical Oncology/College of American Pathologists Guideline Recommendations for Immunohistochemical Testing of Estrogen and Progesterone Receptors in Breast Cancer. J. Clin. Oncol. 2010, 28, 2784-2795. [CrossRef]

42. Rakha, E.A.; El-Sayed, M.E.; Lee, A.H.S.; Elston, C.W.; Grainge, M.J.; Hodi, Z.; Blamey, R.W.; Ellis, I.O. Prognostic Significance of Nottingham Histologic Grade in Invasive Breast Carcinoma. J. Clin. Oncol. 2008, 26, 3153-3158. [CrossRef] [PubMed]

43. Liu, Y.; He, M.; Zuo, W.-J.; Hao, S.; Wang, Z.-H.; Shao, Z.-M. Tumor Size Still Impacts Prognosis in Breast Cancer With Extensive Nodal Involvement. Front. Oncol. 2021, 11, 585613. [CrossRef] [PubMed]

44. Witz, I.P. Tumor-microenvironment interactions: Dangerous liaisons. Adv. Cancer Res. 2008, 100, $203-239$.

45. Chun, E.; Lavoie, S.; Michaud, M.; Gallini, C.A.; Kim, J.; Soucy, G.; Odze, R.; Glickman, J.N.; Garrett, W.S. CCL2 Promotes Colorectal Carcinogenesis by Enhancing Polymorphonuclear Myeloid-Derived Suppressor Cell Population and Function. Cell Rep. 2015, 12, 244-257. [CrossRef]

46. Valković, T.; Lučin, K.; Krstulja, M.; Dobi-Babić, R.; Jonjić, N. Expression of monocyte chemotactic protein-1 in human invasive ductal breast cancer. Pathol. Res. Pract. 1998, 194, 335-340. [CrossRef]

47. Yang, H.; Zhang, Q.; Xu, M.; Wang, L.; Chen, X.; Feng, Y.; Li, Y.; Zhang, X.; Cui, W.; Jia, X. CCL2-CCR2 axis recruits tumor associated macrophages to induce immune evasion through PD-1 signaling in esophageal carcinogenesis. Mol. Cancer 2020, 19, 41. [CrossRef] [PubMed]

48. Xue, C.-B.; Wang, A.; Meloni, D.; Zhang, K.; Kong, L.; Feng, H.; Glenn, J.; Huang, T.; Zhang, Y.; Cao, G.; et al. Discovery of INCB3344, a potent, selective and orally bioavailable antagonist of human and murine CCR2. Bioorganic Med. Chem. Lett. 2010, 20, 7473-7478. [CrossRef] [PubMed]

49. Roblek, M.; Strutzmann, E.; Zankl, C.; Adage, T.; Heikenwalder, M.; Atlic, A.; Weis, R.; Kungl, A.; Borsig, L. Targeting of CCL2-CCR2-Glycosaminoglycan Axis Using a CCL2 Decoy Protein Attenuates Metastasis through Inhibition of Tumor Cell Seeding. Neoplasia 2016, 18, 49-59. [CrossRef] [PubMed]

50. Lim, S.Y.; Yuzhalin, A.; Gordon-Weeks, A.N.; Muschel, R.J. Targeting the CCL2-CCR2 signaling axis in cancer metastasis. Oncotarget 2016, 7, 28697-28710. [CrossRef]

51. Lepique, A.P.; Daghastanli, K.R.P.; Cuccovia, I.M.; Villa, L.L. HPV16 Tumor Associated Macrophages Suppress Antitumor T Cell Responses. Clin. Cancer Res. 2009, 15, 4391-4400. [CrossRef] [PubMed] 
52. Allavena, P.; Mantovani, A. Immunology in the clinic review series; focus on cancer: Tumour-associated macrophages: Undisputed stars of the inflammatory tumour microenvironment. Clin. Exp. Immunol. 2012, 167, 195-205. [CrossRef]

53. Predina, J.; Eruslanov, E.; Judy, B.; Kapoor, V.; Cheng, G.; Wang, L.-C.; Sun, J.; Moon, E.K.; Fridlender, Z.G.; Albelda, S.; et al. Changes in the local tumor microenvironment in recurrent cancers may explain the failure of vaccines after surgery. Proc. Natl. Acad. Sci. USA 2013, 110, E415-E424. [CrossRef] [PubMed]

54. Sha, W.; Brune, B.; Weigert, A. The multi-faceted roles of $€$ prostaglandin E2 in cancer-infiltrating mononuclear phagocyte biology. Immunobiology 2012, 217, 1225-1232. [CrossRef]

55. Shurin, M.R. Dual role of immunomodulation by anticancer chemotherapy. Nat. Med. 2013, 19, 20-22. [CrossRef] [PubMed] 